\title{
Ethnicity Factors in Language Learning: Interest in Learning English among Papuan Students at Jayapura
}

\author{
Linda Safitri ${ }^{1}$, Suhono ${ }^{2}$ \\ ${ }^{1}$ Universitas Islam Negeri (UIN) Raden Mas Said Surakarta, Indonesia \\ ${ }^{2}$ Institut Agama Islam Ma'arif NU (IAIMNU) Metro Lampung, Indonesia
}

suhono120708@gmail.com*

\begin{tabular}{|c|c|}
\hline \multirow[b]{2}{*}{$\begin{array}{c}\text { ARTICLE INFO } \\
\text { Article history: } \\
\text { Received } \\
\text { October 30, } 2021 \\
\text { Revised } \\
\text { December 02, } \\
2021 \\
\text { Accepted } \\
\text { December 10, } \\
2021\end{array}$} & Abstract \\
\hline & $\begin{array}{l}\text { This research discused the phenomenon of the interest in learning English among } \\
\text { Papuan students, especially in the Jayapura university. The purpose of this } \\
\text { research was to find out and examine emergence of interest in learning and } \\
\text { ethnicity factors that influence among Papuan students. The researchers used a } \\
\text { quantitative approach with a descriptive method. The data collection technique } \\
\text { used observation, interviews, and documentation study. The data data collection } \\
\text { tools in the form of observation, questioner, interview, and documentation. The } \\
\text { research findings showed that the interest in learning English among Papuan } \\
\text { students still low, it can be seen from the score of students learning in the class, } \\
\text { this was due to the ethnicity inherent in the people of the Papua. Based on the } \\
\text { observations, interviews and documentations that the researcher carried out } \\
\text { proved that Papuan students and students of other ethnic group has not been well } \\
\text { involved in English learning activities in the class }\end{array}$ \\
\hline \multirow[b]{2}{*}{ Published by } & $\begin{array}{l}\text { Keywords: Ethnicity Factor Language, Ethnicity Papuan Students, English } \\
\text { Learning Interest }\end{array}$ \\
\hline & $\begin{array}{l}\text { Lembaga Penelitian dan Pengabdian Kepada Masyarakat } \\
\text { Institut Agama Islam Negeri Metro }\end{array}$ \\
\hline Website & http://e-journal.metrouniv.ac.id/index.php/tapis/index \\
\hline \multicolumn{2}{|c|}{$\begin{array}{l}\text { This is an open access article under the CC BY SA license } \\
\text { https://creativecommons.org/licenses/by-sa/4.0/ }\end{array}$} \\
\hline
\end{tabular}

\section{INTRODUCTION}

In college, English as a foreign language is one of the subjects that must be taken by students. English as a foreign language is a good first step to being able to communicate with other people internationally. English language has become the main global lingua franca for two reasons, namely geographical-historical and socio-cultural (Shaidullina, 2020; Kucukoglu, 2019; Ma, 2017). English is spread in the global world through the migration of English-speaking people, colonization by the British, America's role and influence on a global scale, international communication, media, technology and others.

The position of English as a foreign language for the Indonesian people makes this language not widely mastered by the Indonesian people in general. In the process of learning English, the community and students must have experienced difficulties or obstacles in learning. Not a few students in Indonesian universities have difficulty 
communicating in English. English is an international language used in various fields (Rao, 2019; Turan, Z., \& Akdag-Cimen, 2020). Learning English is very complex because English has four abilities, namely listening, speaking, reading, and writing and has three additional abilities, namely grammar, vocabulary and pronounciation. Many of students think that English is a difficult language to understand and it takes a long time to learn it. As for the obstacles that become problems, for example, the verbal sounds of English vocabulary are difficult to learn because the writing and pronunciation are very different, then the limitations of the media in learning English. Students study in class when there are having English lecture class only and even then if the teacher is always active in teaching. A very strong reason could be the teaching method of lecturers and lecturers who are always monotonous (not changing) the lecturers do not understand the characteristics of each student due to weak psychological factors in identifying students in English learning needs. In addition, obstacles can come from the family economy, students do not have learning support tools such as laptops, money to buy books and others.

Problems in learning English do not only occur at the elementary, middle and high school levels. But also in the college. Not only English study programs have experienced this, but it also applies to students who are not majoring in English, of course to Papuan students. It was found in Papuan students at several universities in Jayapura City that many students have low English communication skills due to several factors that influence it. Not a few Papuan students who come from the mountains they seek knowledge in Jayapura City, from the area of origin of these students they have many obstacles and obstacles that make interest in learning English very low. It could be said that they know English courses for the first time when they enter college at the beginning of the semester, where English courses are general basic subjects which every study program requires that these courses be required. This is because many teachers find it difficult to reach remote areas so that in English subjects no one is able to fill in the material in the classroom.

Many researchers have done analysis of the interest english learning those are M. Arif Rahman Hakim coms from IAIN Bengkulu (2017) he was find out The identify that nationality, race and ethnicity are the ones that are often challenged in learning English. Nationality is often ignored because it is considered to have little role in development. English language learners worldwide, different national identifications are available, depending on the learners studying within their own country. The second researcher is Nofiyana comes from FKIP Universitas Tadulako (2018). The purpose of this study was to describe students' interest in learning Indonesian in class $X$ at SMA Negeri 1 Balaesang. This type of research uses qualitative descriptive method. Data collection techniques using observation, interviews and questionnaires. Based on the results of the data analysis, it can be seen from the questionnaire distributed that the percentage of students' interest in learning materials are not enough. This is due to the lack of student attention and limited facilities and infrastructure. 
From several factors that underlie the weak level of student learning in universities, the researcher conduct to identify interest in learning English among Papuan students, especially in the city of Jayapura. Jayapura city as the capital of Papua province which is inhabited more than half from outside the island of Papua. The mixing of the population causes ethnic variations from various regions to emerge. Diversity makes Indonesia have a character with different cultural values from one another. The Papuan people are synonymous with black skin and curly hair, with a fairly distinctive style of speech, namely a firm dialect and a fast speech tempo that makes it difficult for most of the interlocutors from outside the island of Papua to understand. Hence, the aim of this study was to find out and examine emergence of interest in learning and ethnicity factors that influence among Papua students.

\section{Literature Review}

Ethnicity is a group of people who have a common history, ancestry, origin and language which is reflected in distinctive symbols, such as religion, clothing and traditions. In short, ethnicity is defined as a group of people who are culturally different from other groups of people. A nation and state may have various ethnicities that can be distinguished from other ethnic groups (International Encyclopedia of Social Science, vol.3). Elisabeth (2012) stated that based on ethnicity the indigenous Papuans are divided into two major ethnic groups, 1 . Melanesian ethnicity who inhabits coastal areas and islands. 2. Ethnic Papuans who live in the highlands.

The indigenous people of Papua are descendants of ancestors who have the Negroid race. Physically, the Papuan people are similar to African Negroids who have the characteristics of a tall, straight body identity, black skin color and curly hair.

As stated by Ratcliffe (2006) ethnic groups have origins and ancestors, have the same past experience or knowledge, have the same group identity, and this similarity is reflected in five factors, namely (1) kinship, (2) religion. (3) language, (4) location of group settlement, and (5) physical appearance. The word ethnicity is like what Barker (2004: 76) explains, namely something that cannot be seen as something that stands alone. Ethnicity is a rational concept based on the category of self-identification. Barker also explained that if these conditions were met, there would be no ethnicity, because ethnicity is essentially an aspect of a relationship pattern, not belonging to a group.

Research has shown that factors such as positive learner and teacher attitudes, which are interrelated to motivation, must be sustained for successful transfer of language learning (Deweale, 2019, Finocchiaro, 1982; Ngeow, 1998; Lasagabaster, 2017). To foster positive attitudes and to motivate learning, in particular, the learning of English as a Second Language, an environment conducive to learning must be created. Factors that help create such an environment include: learning situation that has a "low affective filter" (Krashen, 1987) whereby the learners learn to use the language in a nonthreatening and fun environment. Otherwise, learners will feel uncomfortable and insecure which will further induce a "psychological barrier" to communication and learning (Robets, et al., 2020) providing various types of input which are auditory,

\section{8}


visual, sensory, verbal and non-verbal in nature and input which is comprehensible or a little beyond the level of the learner $(i+1)$ providing a continuous and consistent exposure to the language being learned an environment where the teachers and the students are supportive and encouraging having access to situations wherein students are able to use the language as a "natural means of communication" (Littlewood, 1995; ). These factors should be present in any language learning program. The enrichment part of a language curriculum must encompass these factors which encourage successful transfer and learning of the target language.

A language enrichment program should not be seen as separate from the school curriculum. Instead, it needs to complement and strengthen the development of language proficiency of students in schools. Therefore, what occurs in the language classrooms must be extended beyond the walls of the classrooms so that a link is created between what is learned in the classrooms with what occurs outside of the classrooms. A healthy balance has to be created between the immediate needs of examinations and the long-term needs of communicative competence. Furthermore, within an enrichment framework other interrelated factors such as the teachers philosophy, theories, and experience of the language; the contemporary climate of the teaching situation (which is affected by such factors as the political, economic, and technological advances of the country); the available teaching aids and materials ; and the constant demand to prepare students for the standardized exams all play interconnected roles within the school language curriculum

\section{METHOD}

In this study, the type of research method used is qualitative research. The data in this research are 100 papua students in some of Universities in Jayapura (Health Polytechnic of Jayapura, IAIN Fattahul Muluk Papua, Sain and Technology University Jayapura). The researcher used simple random sampling by taking the Papuan students. In this study, data were obtained through two sources, namely primary data and secondary data. Primary data is data obtained directly from research subjects, consisting of Papuan students university at (Health Polytechnic of Jayapura, IAIN Fattahul Muluk Papua, Sains and Technology University of Jayapura). As for secondary data, namely data obtained by researcher to support primary data, which consists of theories about ethnicity, books related to learning English and report results both while in the research field, and in other places. both offline and online for the current situation as well as documentation that has relevance in this study. In this, the researcher collected data through observation, interviews, questionnaire and documentation, after that the researcher retells the data which had been analyzed in the form of conclusion. In analyzing the data the researchers used formula:

$$
\begin{aligned}
P= & \frac{F}{N} \times 100 \% \\
& \text { Description: }
\end{aligned}
$$


$\mathrm{P}=$ percentage of students' interest in learning

$\mathrm{F}=$ Frequency being searched the percentage (number of answers from each alternative chosen)

$\mathrm{N}=$ Total maximum score

$100 \%=$ fixed number

(Anas Sudjono, 2011)

\section{RESULT AND DISCUSSION}

Based on the results of research obtained from questionnaire data that Papuan students in 3 universities in Jayapura city (Health Poytechnic of Jayapura, IAIN Fattahul Muluk Papua, Sains and Technology of Jayapura) basically they have an interest in learning English and some have very little interest in participating in learning these courses. It can be seen in table 1.1 where there are $31 \%$ happy and $34 \%$ quite happy with learning English. This means that students show that they have an interest in learning so that they can follow the lesson well. This is also seen in table.1.2. shows that there are $48 \%$ of students sometimes pay attention to lessons in class. They have tried to pay attention to English learning materials when the lecturers teach in class. In this case, it can be said that students actually have an interest but it cannot be said to be optimal because they are still afraid to express ideas in questions and answers. Or it can be said that there are still some students playing, joking with other friends when the lecturer explains the material in class. It can be said that these students are not serious in accepting English learning so that the learning atmosphere is not conducive because they make their own activities during learning. This condition makes it difficult for students to learn.

Tabel 1. Statement of English Learning Difficulties

\begin{tabular}{|c|c|c|c|}
\hline No & Statement & Frequency & Persentation \\
\hline 1 & Very often & 21 & $21 \%$ \\
\hline 2 & Often & 45 & $45 \%$ \\
\hline 3 & Quite often & 16 & $16 \%$ \\
\hline 4 & Sometimes & 15 & $15 \%$ \\
\hline 5 & Never & 3 & $3 \%$ \\
\hline \multicolumn{2}{|c|}{ Account } & 100 & $100 \%$ \\
\hline
\end{tabular}

Table 2. The Statement of Fun Athmosphere in the Class

\begin{tabular}{|c|c|c|c|}
\hline No & Statement & Frequency & Persentation \\
\hline 1 & Very often & 17 & $17 \%$ \\
\hline 2 & Often & 45 & $45 \%$ \\
\hline 3 & Quite often & 15 & $15 \%$ \\
\hline
\end{tabular}




\begin{tabular}{|c|c|c|c|}
\hline 4 & Sometimes & 17 & $17 \%$ \\
\hline 5 & Never & 6 & $6 \%$ \\
\hline \multicolumn{2}{|l|}{ Account } & 100 & $100 \%$ \\
\hline
\end{tabular}

The statement can be seen in table 1 that there are $45 \%$ of students experiencing difficulties in learning English. This may be due to the material being taught has not been fully digested by them. Each student has a different absorption capacity so that there are students who quickly accept the material and there are also students who have very slow absorption even though the lecturer has created a pleasant atmosphere in learning activities. Students stated that $45 \%$ of lecturers created a pleasant atmosphere in the classroom as shown in table 2, it can be said that the role of the lecturer is very influential on student learning interest.

Table 3 The Statement of Active Asking in the Class

\begin{tabular}{|c|c|c|c|}
\hline No & Statement & Frequency & Persentation \\
\hline 1 & Very often & 8 & $8 \%$ \\
\hline 2 & Often & 15 & $15 \%$ \\
\hline 3 & Quite often & 10 & $10 \%$ \\
\hline 4 & Sometimes & 63 & $63 \%$ \\
\hline 5 & Never & 4 & $4 \%$ \\
\hline \multicolumn{2}{|c|}{ Account } & 100 & $100 \%$ \\
\hline
\end{tabular}

A student who is not active in class does not mean they are not interested in the learning. They are active in the ongoing learning activities because they are confident to find out something difficult that they have not understood besides that there are still afraid or hesitant in conveying his opinion. In table 3 it can be seen that $63 \%$ of students sometimes ask when they have difficulty in learning material, this can be said that they are afraid or embarrassed to ask the lecturer. Students who look passive or don't ask questions do not mean they always understand and understand all the material being taught, they may be lazy to know and ashamed to be afraid of the lecturer.

Table 4. The Statement of the Completeness of Facility and Infrastructure the Study

\begin{tabular}{|c|c|c|c|}
\hline No & Statement & Frequency & Persentation \\
\hline 1 & Very often & 20 & $20 \%$ \\
\hline 2 & Often & 63 & $63 \%$ \\
\hline 3 & Quite often & 5 & $5 \%$ \\
\hline 4 & Sometimes & 12 & $12 \%$ \\
\hline 5 & Never & - & $0 \%$ \\
\hline \multicolumn{2}{|c|}{ Account } & 100 & $100 \%$ \\
\hline
\end{tabular}


Viewed in the completeness of facilities and infrastructure in table 4 shows the number of students $50 \%$ less available, it can be said that the tools to support their learning activities are still lacking. For example, a laptop is a student's equipment to do assignments, presentations, and others. It turns out that not all students have their own laptop, they depend on a friend's loan or even an hourly rental on a computer rental. However, it's also not all students can rent a computer per hour to do assignments or other things, it's due to economic factors from the family. Because they have to spend a lot of money on hourly rentals and have not printed them, they may never turn in assignments. In addition, learning companion books are the main means to increase knowledge of the material taught in class, they do not have that at all. So, these students rely on the materials provided by the lecturer when teaching in class. This factor also for hinders student interest in learning English and student achievement. Adequate facilities and infrastructure will attract students' interest in learning.

Table 5. The Statement to Repeat the Material at Home

\begin{tabular}{|c|c|c|c|}
\hline No & Statement & Frequency & Persentation \\
\hline 1 & Very often & 7 & $7 \%$ \\
\hline 2 & Often & 27 & $27 \%$ \\
\hline 3 & Quite often & 10 & $10 \%$ \\
\hline 4 & Sometimes & 26 & $26 \%$ \\
\hline 5 & Never & 30 & $30 \%$ \\
\hline \multicolumn{2}{|c}{ Account } & 100 & $100 \%$ \\
\hline
\end{tabular}

Table 6. The Statement of Study or not during Test

\begin{tabular}{|c|c|c|c|}
\hline No & Statement & Frequency & Persentation \\
\hline 1 & Very often & - & $0 \%$ \\
\hline 2 & Often & 12 & $12 \%$ \\
\hline 3 & Quite often & 27 & $27 \%$ \\
\hline 4 & Sometimes & 41 & $41 \%$ \\
\hline 5 & Never & 20 & $20 \%$ \\
\hline \multicolumn{2}{|c|}{ Account } & 100 & $100 \%$ \\
\hline
\end{tabular}

In table 5 seen $30 \%$ stated that students never repeat the material at home. If a student does not have an interest in learning English, they will also not study trying to deepen the material for achievement. Moreover, in table 6 it can be seen that $41 \%$ of students stated that they sometimes study when there is a test. This illustrates that students are not optimal in their interest in learning English due to lack of creativity and effort to achieve successful achievements. Students are expected to have an interest and be able to develop their interest in learning in order to understand, understand and accept the material taught in class. A student who has an interest tends to have high motivation to achieve that desire. In addition, high motivation to participate in ongoing 
learning activities. With interest, they will try how to get the facilities and infrastructure that support the learning process. In addition, the motivation of a teacher is also very influential in the growth of interest in learning.

Other study also proven that in learning activities, the role of educator or teachers are needed for smooth learning process. Educators act as helper, pusher and mentor for participants educate. Therefore, the role of educators are very influential. Teachers can use the methods that fun to make interested students learn to speak English (Thordardottir, 2021; Wimolmas, 2013; Fryer, 2019). Because what is being faced is students with various character, then the teacher factor that's fun enough needed. Usually students it will be easy to catch lessons if they feel happy and comfortable with person who guides them.

The teacher serves as teacher and mentor for every his student. Because that, a teacher must have level good quality so can be used as a role model for every student. This matter also applies in the process English learning. Good for learning the language English at school and course institution, the teacher will big influence on the result of the learning process (Briz-Ponze, et al., 2017; Sun, Y., \& Gao, 2020). The teacher who motivate students to learn often develop intrinsic motivation students to learn for knowledge (Csikszentmihalyi, 2014). Learners often find it difficult to have interest in course. As a result, they depends on their teacher to develop interest so they can learn English. It is important for them because the test in English often determines is a students can be stay in class or have possibility to go to higher level such as at the junior high, high school level or even for education University. Significantly, Keller, et al,m (2014) states that "teacher enthusiasm, help students are interested and motivated in study".

Other studies show that the important processes that influence participant motivation students involve the teacher's expectations to keep learning and improving performance (Koopmans et al, 2014). The researcher on teacher expectations within 25 the past year has discussed issues like how form hope teacher, how do they communicate to students them, and how these expectations affect results proposes different view on the issue of "participant motivation educate ", how can the teacher get students who are interested in learning English as a second language.

This clearly highlights the importance of a teacher to develop interest in language learning. However, the teacher's expectations for student academic performance must be based on the formation facilitating relationship favorable outcome (Njoroge \& Nyabuto, 2014). On learning process students about language English is still basic, the the student will accept whatever is taught by the teacher. Even when the teacher teaches wrong thing though, the student does not will be able to fix it because no english for beginners, the teacher has a distant role more important than with process learn english for advanced level. In class english for beginners, general understanding of language participant's English education is still very basic, maybe even still zero. Because that's the role of the teacher in language learning English for beginners be a very important factor important. If the teacher who teach language class This beginner's 
English is not a professional in the field, of course will be able to provide understanding that wrong to every student guided by him. When a person's understanding know that what is taught the teacher the wrong. The problem is, error this will always be considered correct by participant teach it if it doesn't exist people who try to fix it. To solve this problem, many course institutions in the end using native teacher as teaching staff. Native teacher means teacher who come from a country that use English as a language to communicate daily. on English class for beginner, native teacher who teaching should also be able speak Indonesian.

\section{CONCLUSION}

The conclusion of this study shows that the interest in learning English among Papuan students is still low. This situation is influenced by ethnic factors, those are; First, in terms of the language itself. Papuan students did not able to understand English because they are already familiar with Malay. It can be seen that the Jayapura City Elementary School has English subjects but still having no teachers to teach at the school in disadvantaged areas. Second, the ethnic factor from the hinterland, students who come from the hinterland who have not been touched by English subjects, they have very little basic knowledge in English. Third, the factor of inadequate learning facilities that makes students' interest in learning decreases to increase their knowledge. Students who have an interest in learning tend to try to find something that they do not know and understand.

\section{ACKNOWLEDGMENT}

The researchers thank to (LP2M) UIN Raden Mas Said Surakarta. This work was also supported by Lembaga Penelitian dan Pengabdian Masyarakat (LP2M) Institut Agama Islam Ma'arif NU (IAIMNU) Metro Lampung

\section{AUTHOR CONTRIBUTION STATMENT}

All authors contributed in the preparation of the manuscript of this article, all authors have read and approved the final manuscript.

\section{REFERENCES}

Arikunto Suharsimi. 1996. Prosedur Penelitian Suatu Pendekatan Praktek. Yogyakarta, Renika Cipta.

Budiyarti, Yeti. 2011. Minat Belajar Siswa Terhadap Mata Pelajaran Bahasa Indonesia di kelas XI SMA PGRI. Skripsi. UIN Syarif Hidyatullah.

Briz-Ponce, L., Pereira, A., Carvalho, L., Juanes-Méndez, J. A., \& García-Peñalvo, F. J. (2017). Learning with mobile technologies-Students' behavior. Computers in human behavior, 72, 612-620.

Chris Barker, The Sage Dictionary of Cultural Studies (London : SAGE Publications Ltd, 2004)h. 76. 
Csikszentmihalyi, M. (2014). Intrinsic motivation and effective teaching. In Applications of flow in human development and education (pp. 173-187). Springer, Dordrecht.

Christiani, Lintang Citra, 2017. Representasi Identitas Etnis Papua Dalam Serial Drama Diam- Diam Suka Universitas Tidar. Juranal Komunikasi dan Kajian Media, Volume 1, Nomor 1, Oktober 2017: 15-30.

Dewaele, J. M. (2019). The effect of classroom emotions, attitudes toward English, and teacher behavior on willingness to communicate among English foreign language learners. Journal of Language and Social Psychology, 38(4), 523-535.

Dimyati, Mudjiono. 2002. Belajar dalam Bidang Pendidikan. Program Pascasarjana Universitas Negeri Jakarta. Jakarta.

Finocchiaro, M. (1982). Motivation: Its Crucial Role in Language Learning. (ERIC Document Reproduction Service No. ED 223 3085)

Fryer, L. K. (2019). Getting interested: Developing a sustainable source of motivation to learn a new language at school. System, 86, 102120.

Hatalia, Amrazi, Rustiyarso. Interaksi Sosial Mahasiswa Papua dengan Berbagai Mahasiswa Etnik Lain Studi Kasus di Rusunawa UNTAN. Program Studi Pendidikan Sosiologi FKIP UNTAN, Pontianak.

Keller, M. M., Goetz, T., Becker, E. S., Morger, V., \& Hensley, L. (2014). Feeling and showing: A new conceptualization of dispositional teacher enthusiasm and its relation to students' interest. Learning and Instruction, 33, 29-38.

Kucukoglu, H. (2019). Geographical, Historical and Structural Qualities of the Turkish. Intertext, 49(1-2), 110-117.

Krashen, S.D. (1987). Principles and Practice in Second Language Acquisition. New York: Prentice-Hall.

Koopmans, L., Bernaards, C. M., Hildebrandt, V. H., Van Buuren, S., Van der Beek, A. J., \& De Vet, H. C. (2014). Improving the individual work performance questionnaire using rasch analysis. Journal of applied measurement, 15(2), 160175.

Lasagabaster, D. (2017). Language learning motivation and language attitudes in multilingual Spain from an international perspective. The Modern Language Journal, 101(3), 583-596.

Ma, Q. (2017). A multi-case study of university students' language-learning experience mediated by mobile technologies: A socio-cultural perspective. computer assisted language learning, 30(3-4), 183-203.

Megawati, F.,\& Anugerahwati, M. (2012). Comic Strips: A study on the Teaching Of Writing Narrative Texts to Indonesian Efl Students. Teflin, 23 (2).

Nawawi, Hadari. Metode Penelitian Sosial. Cet III: Yogyakarta: Gajah Mada University Press, 1998.

Ngeow, Karen Yeok-Hwa. (1998). Motivation and Transfer in Language Learning. (ERIC Document Reproduction Service No. ED 427 318). 
Njoroge, P. M., \& Nyabuto, A. N. (2014). Discipline as a factor in academic performance in Kenya. Journal of Educational and Social Research, 4(1), 289289.

Rao, P. S. (2019). The role of English as a global language. Research Journal of English, 4(1), 65-79.

Rahmawati, I.F. (2011). Improving Eighth Graders' Reading Comprehension Through Autonomous Strategy. SKRIPSI Jurusan Sastra Inggris- Fakultas Sastra UM.

Rukmini, A.S. (2011) The Implementation of Teacher Corrective Feedback in Teaching

Roberts, S. O., Weisman, K., Lane, J. D., Williams, A., Camp, N. P., Wang, M., ... \& Griffiths, C. (2020). God as a White man: A psychological barrier to conceptualizing Black people and women as leadership worthy. Journal of personality and social psychology.

Shaidullina, A. R., Sakhipova, Z. M., \& Sadykova, L. R. (2020). Linguistic creativity as compliance with the socio-cultural context and communication representations. Russian Linguistic Bulletin, (2 (22)), 79-82.

Sun, Y., \& Gao, F. (2020). An investigation of the influence of intrinsic motivation on students' intention to use mobile devices in language learning. Educational Technology Research and Development, 68(3), 1181-1198.

Thordardottir, E. (2021). National language in a globalised world: are L1 and L2 adolescents in Iceland more interested in learning English than Icelandic?. Journal of Multilingual and Multicultural Development, 1-16

Wimolmas, R. (2013). A survey study of motivation in English language learning of first year undergraduate students at Sirindhorn International Institute of Technology (SIIT), Thammasat University. Language Institute, Thammasat University.

Writing Descriptive Text to The Second Year Students of SMPN 1 Tunjungan In 2010/2011 Academic Year (Doctoral Dissertation Universitas Muhammadiyah Surakarta).

Sadirman, A.M. (2008). Interaksi \& Motivasi Belajar Mengajar. Jakarta : PT. Raja Grafindo Persada.

Sinaga, F. (2010). Peranan Bahasa Inggris Dalam Era Globalisasi. http://kursus inngris.wordpress.com, diakses tanggal 14 oktober 2019.

Slameto, Belajar dan Faktor-Faktor yang Mempengaruhinya. Jakarta: Rineka Cipta, hlm.180.

Flipped classroom in English language teaching: a systematic review. Computer Assisted Language Learning, 33(5-6), 590-606

Vick, Dwight, dan Ishiyama, John.2011. Ethnic and Identity Politics. Editor Jhon T Ishiyama \& Marjike Breuning, 21st Political Science. Los Angeles: Sage Publicatios. Hal 217-224. 


\section{Copyright Holder :}

(C) Linda Safitri \& Suhono (2021)

First Publication Right

(C) Tapis : Jurnal Penelitian Ilmiah

This article is under:

CC BY SA 